unless the third party defendant happened to live within the state in which suit were being brought. The restrictive interpretation of 4 (d)(7) would have a similar effect on the operation of Rule 19, which provides for necessary joinder. Since indispensable parties could not be joined unless they could be served in the state of the suit, an increased number of actions would be dismissed pursuant to Rule 12(b) for failure to join all indispensable parties. Rule 22(1) permits the interpleading of parties so as to prevent the holder of funds from being exposed to double liability. Restrictions on out-of-state service would quite obviously minimize the usefulness of this Rule in avoiding double liability. ${ }^{33}$ These collateral effects of the restrictive interpretation of $4(d)(7)$ are far reaching and militate for disavowance of this interpretation.

Finally, considerations of providing for a just trial warrant acceptance of the broad application of 4 (d)(7). The suit could then be filed in a convenient forum-the state in which the cause of action arose. It is there that evidence and witnesses are most conveniently available. The injured person is spared the expense of travelling to the district of the nonresident defendant. When a nonresident drives upon the highways of another state and becomes involved in an accident, the obligation to return for suit is not an undue burden. ${ }^{34}$

\footnotetext{
${ }^{33}$ In addition to rule interpleader, provided for by Rule $22(1)$, there exists a statutory interpleader action created by 28 U.S.C. $\$ \$ 1335,1397,2361$ (1958), and acknowledged in Rule 22(2). The interpretation given Rules $4(d)(7)$ and $4(f)$ would only affect service of process in rule interpleader proceedings since nationwide service is provided for in statutory interpleader actions. 28 U.S.C. $\$ 2361$ (1958).

${ }^{31}$ In addition it has been pointed out that the delay in the state courts is a major factor to be taken into consideration. "For example, the trial courts in Cook County, Illinois, are presently some four to five years behind on their trial calendars. To place the additional burden on them of handling the cases which are now filed in the federal court under diversity jurisdiction would be to cause a breakdown of the Illinois judicial system." Kurland, supra note 22 , at 197 n.52.
}

\title{
THE DEFENSE OF ANTITRUST ILLEGALITY IN CONTRACT ACTIONS
}

In 1958, the Supreme Court, in Kelly v. Kosuga, ${ }^{1}$ restated its standards for recognition of the defense of antitrust illegality to an action brought to enforce a contract. That case, together with two subsequent cases decided by the Sixth and Seventh Circuit Courts of Appeals, ${ }^{2}$ indicates the need for a reexamination of the traditional doctrines ${ }^{3}$ and the possibility that a formulation may be

1358 U.S. 516 (1959).

2 Beloit Culligan Soft Water Service, Inc. v. Culligan, Inc., 274 F.2d 29 (7th Cir. 1959); Tampa Elec. Co. v. Nashville Coal Co., 276 F.2d 766 (6th Cir. 1960).

3 The basic rule is that the courts will refuse absolutely to enforce illegal contracts. The harshness of this rule, if rigidly applied, has led to the creation of a number of exceptions. Three major exceptions are (1) contracts which are only "collaterally" illegal, (2) contracts in which the illegal portion is sufficiently independent to be deemed severable, and (3) contracts where the plaintiff is not in pari delicto with the defendant. Such contracts may be enforced 
found which will more effectively reconcile the competing interests involved. As will be indicated in the following discussion, the Supreme Court's dilemma appears to arise from the necessity, under the traditional doctrines, of choosing between the enforcement of a contract which would further an illegal purpose on the one hand, and, on the other, the refusal of all recovery, which might often result in unjustly enriching the defendant at the plaintiff's expense and imposing upon the plaintiff a disproportionate penalty for his illegal acts. It will be suggested that by application of principles of restitution in this area, the Court would not only be able to achieve greater justice between the parties to the contract, but it might also be able to avoid the often strained application of the complex doctrines which it has developed in an effort to mitigrate the undue harshness of the traditional rule forbidding enforcement of illegal contracts.

\section{HISTORY OF THE DEFENSE}

In a series of cases dating from 1902 to 1958 , the Supreme Court has made repeated efforts to clarify and demonstrate its concept of the proper application of the defense. ${ }^{4}$ In Kelly v. Kosuga, the most recent in this line of cases, plaintiff Kosuga and an associate were owners of about 1,000 carloads of onions. Kelly, an onion grower, agreed along with other growers, to purchase 287 carloads of onions at the prevailing market price. The agreement between Kelly and Kosuga covered fifty carloads and included reciprocal promises not to deliver onions on the futures market. The purpose of the arrangement admittedly was to discourage Kosuga from delivering onions on the futures market in satisfaction of contract obligations, since this would have depressed onion prices. ${ }^{5}$ Kelly made a partial payment as required by the contract and took delivery of thirteen carloads. After the agreement was concluded, the price of onions fell sharply. Kelly then refused to accept delivery of any of the remaining thirtyseven carloads or to pay the amount due by the terms of the contract. Due to spoilage, the onions in storage had become substantially valueless. Kosuga

despite the taint of illegality. Where recovery on the contract is not available, restitution is also denied. See Restatexent, Lontracts § 598 (1932); 5 Wintiston, Contracts $\$ 1630$ (1937); CHeshire and Fifoot, The Law of ConTract 258 (1949). The defense of antitrust illegality has received attention recently in cases other than those cited in note 2 supra. See Kentucky Rural Electric Corp. v. Moloney Electric Co., 175 F. Supp. 251 (W.D. Ky. 1959); Reserve Mining Co. v. Mesabi Iron Co., 172 F. Supp. 1 (D. Minn. 1959). See also Handler, Recent Antitrust Developments, 14 RECORD of N.Y.C.B.A. 318 (1959); Note, Contracts-Defense of Illegality -Violation of Antitrust Laws, 13 Sw. L.J. 535 (1959); Note, Coniracts . . Sherman Act Violation, 45 A.B.A.J. 616 (1959); Note, Sherman Act Violation as a Contract Defense, 73 HARV. L. REV. 203 (1959).

1 Kelly v. Kosuga, 358 U.S. 516 (1959); Bruce's Juices v. American Can Co., 330 U.S. 743 (1947); Small Co. v. Lamborn \& Co., 267 U.S. 248 (1925); Wilder Mfg. Co, v. Corn Prod. Ref. Co., 236 U.S. 165 (1915); Continental Wall Paper Co. v. Louis Voight \& Sons Co., 212 U.S. 227 (1909); Connolly v. Union Sewer Pipe Co., 184 U.S. 540 (1902). For an indication of early dissatisfaction with the approach taken by the Supreme Court in these cases see Gelhorn, Contracls and Public Policy, 35 CoLUM. L. REv. 679 (1935).

${ }^{5}$ See Brief for Petitioner, pp. 5-6, Kelly v. Kosuga, 358 U.S. 516 (1959). 
sold what he could at a very low price in mitigation of damages and brought this action to recover his loss, including storage charges.

The defendant set up the agreement not to deliver onions on the futures market as an affirmative defense, alleging the arrangement to be in violation of the Sherman Act ${ }^{6}$ and thus unenforceable. The district court granted plaintiff's motion to strike the defense and rendered judgment for the plaintiff. ${ }^{7}$ The Court of Appeals for the Seventh Circuit affrmed. ${ }^{8}$ The Supreme Court affirmed, holding the non-delivery agreement separable from the contract of sale. The Court was thereby able to conclude that the latter agreement was merely "collateral" to any illegal arrangement which might exist by virtue of the nondelivery clause, rather than that the contract was "inherently" illegal and thus unenforceable.

The Court traced this traditional and oft-employed distinction to its beginnings, in the antitrust illegality cases, in Connolly v. Union Sewer Pipe Co. ${ }^{9}$ Connolly was an action by the seller to recover the price of pipe sold and delivered to the defendants. The defense was that the plaintiff had entered into a combination with other firms that manufactured Akron pipe, and that the conspirators had agreed to keep their prices above the regular market price. It was alleged that the contract in suit was made in furtherance of the ends of this unlawful combination. The Court rejected the defense, commenting:

The purchases by the defendants had no necessary or direct connection with the alleged illegal combination; for the contracts between the defendants and the plaintiff could have been proven without any reference to the arrangement whereby the latter became an illegal combination... The contracts between the plaintiff and the respec-

${ }^{6} 26$ Stat. 209 (1890), as amended, 15 U.S.C. $\$ 1$ (1958). Other antitrust legislation pertinent to this inquiry includes the whole of the Sherman Act, 26 Stat. 209-10 (1890), as amended, 15 U.S.C. $\S \S 1-7$ (1958); the Federal Trade Commission Act, 38 Stat. 717-24 (1914), as amended, 15 U.S.C. $\$ \S 41-58$ (1958); and the Clayton Act, 38 Stat. $730-40$ (1914), as amended, 15 U.S.C. $\S \S 12-27$.

${ }^{7}$ Civil No. 12190, N.D. Ill., Oct. 11, 1957.

${ }^{8} 257$ F.2d 48 (7th Cir. 1958).

${ }^{9} 184$ U.S. 540 (1902). Many cases raising the defense that a particular contract was in restraint of trade and thus was unenforceable were decided prior to the passage of the antitrust statutes. See, e.g., McMullen v. Hoffman, 174 U.S. 639 (1899), and cases cited therein. A reading of these cases reveals a rather ambiguous reference to the collateral-inherent distinction relied on in Connolly. The Connolly case appears, however, to have been the first opinion which relied on the distinction as a self-defined formula.

The earlier cases also reveal a much more receptive attitude on the part of the courts. It almost seems that in the earlier cases the courts were seeking justifications for avoiding enforcement of contracts of questionable legality, while in the later cases, decided under the statutes, the courts seem willing to go to great lengths to justify enforcement of the marginal contracts. An early case of interest is Cincinnati Packet Co. v. Bay, 200 U.S. 179 (1906), in which the defense based on the statute was raised and rejected without reference to Connolly, on the ground that the Sherman Act does not reach contracts between carriers operating between terminal points within one state who cross over into another state during the course of their water voyage. Justice Holmes indicated in this opinion the restrictive future course to be encountered by the defense of antitrust illegality. 
tive defendants were, in every sense, collateral to the alleged agreement between the plaintiff and other corporations, firms or associations whereby an illegal combination was formed for the sale of sewer pipe. ${ }^{10}$

Continental W all Paper Co. v. Louis Voight \& Sons Co. ${ }^{11}$ is the only action on a contract in which the Supreme Court has sustained the defense of antitrust illegality. ${ }^{12}$ In that case the plaintiff-seller sought enforcement of a requirements contract with a minimum price clause. The buyer defended on the grounds that the plaintiff was an illegal combination, and that the contract in question was inextricably connected with and in furtherance of the unlawful ends of the monopoly. Justice Harlan, who had written the majority opinion in Connolly, distinguished that case:

$H$ is [Connolly's] contract was to take certain goods at an agreed price, nothing more, and was not in itself illegal, nor part of nor in execution of any general plan or scheme that the law condemned.13

But Continental was different:

[I] $t$ is admitted by the demurrer [that the contract sought to be enforced] was in fact intended by the parties to be based upon agreements that were and are essential parts of an illegal scheme. ${ }^{14}$

'On the basis of this distinction of the cases, Justice Harlan concluded that the contract in Continental was "inherently" illegal. It is quite difficult to perceive the difference between the cases. The distinction would appear to be one of degree rather than of kind; and as between Comolly and Continental the difference in degree is a very small one indeed. It is suggested that these two cases demonstrate the inadequacy of the collateral-inherent distinction as a self-defined rationale for these cases: The formula appears merely to serve as a cover which

10184 U.S. at 549.

12212 U.S. 227 (1909).

12 The only other significant case found in which the Supreme Court has sustained the defense is Dr. Miles Medical Co. v. Park \& Sons Co., 220 U.S 373 (1911). That was a suit in equity by a manufacturer of medical remedies who had negotiated resale price maintenance agreements with its vendee-wholesalers and retailers. The defendant was a wholesale druggist who had no such contract with the plaintiff. The bill alleged that the defendant had induced other wholesalers who had contracts with the plaintiff to sell plaintiff's goods to the defendant in violation of their contracts. The alleged purpose of the defendant was to cut prices on plaintiff's goods and thus break the resale price maintenance system. The relief sought was an injunction restraining the alleged inducement to breach of contract. The case turned on the validity of the contracts between the plaintiff and its wholesalers. The characteristic that distinguishes this case analytically from those here discussed is that there were no complex policy conflicts similar to those that seem important in, for example, Connolly, Continental, and Kelly, See pp. 768-73 infra. There was no problem of the defendant being unjustly enriched by a judgment holding the agreements invalid and unenforceable. Furthermore, there appears to have been no way in which a judgment of the Court might have compelled the performance of an illegal act.

${ }^{13}$ Continental Wall Paper Co. v. Louis Voight \& Sons Co., 212 U.S. 227, 260 (1909).

11 Id. at 261. 
allows the Court to reach its conclusion on policy grounds which are not always clearly expressed. In Connolly and Costinental, the court was apparently impressed with two things: (1) That somehow the combination in Continental was more reprehensible than it was in Connolly, ${ }_{15}$ and the contract in suit considerably more important to the success of the combination; ${ }^{16}$ and (2) that in Continental the unjust enrichment of the defendant and the disproportionate penalty imposed on the plaintiff by allowing the defense were more than balanced by the importance of not giving the assistance sought to the success of an admittedly illegal scheme. ${ }^{17}$

The defense was sustained in Continental despite the fact that the defendant, as a co-conspirator, was apparently guilty of a violation of the act. Yet in Connolly, where the defendant was not chargeable with a violation, the defense was not allowed. Despite these difficult problems, the collateral-inherent distinction has been relied upon in all subsequent cases decided by the Supreme Court. ${ }^{18}$

- From 1925 to 1946, all cases involving this defense were concluded in the

${ }^{15}$ In Continental the Court said:

"That the combination represented by the plaintiff company is within the prohibitions of the above act of Congress is clear from the facts admitted by the demurrer. We assume, therefore, without discussion-for discussion is unnecessary-that there is a combination, of which the Continental Wall Paper Company is the representative, and that, in violation of that act, such combination was formed with the intent, and will have the effect, directly, to restrain as well as monopolize trade and commerce among the several States and with foreign nations as involved in the manufacture, sale and transportation of wall paper among the several States and with foreign nations." 212 U.S. at 255.

The reference made to the illegal combination in Connolly seems much weaker:

"Assuming, as defendants contend, that the alleged combination was illegal if tested by the principles of the common law, still it would not follow that they could, at common law, refuse to pay for pipe bought by them under special contracts with the plaintiff." Connolly v. Union Sewer Pipe Co., 184 U.S. 540, 545 (1902).

16 "The present suit is not based upon an implied contract of the defendant company to pay a reasonable price for goods that it purchased, but upon agreements, to which both the plaintiff and the defendant were parties, and pitrsuant to which the accounts sued on were made out, and which had for their object, and which it is admitted had directly the effect, to accomplish the illegal ends for which the Continental Wall Paper Company was organized. If judgment be given for the plaintiff the result, beyond all question, will be to give the aid of the court in making effective the illegal agreements that constitute the forbidden combination. These considerations make it evident that the present case is different from the Connolly Case. In that case the court regarded the record as presenting the question whether a voluntary purchaser of goods at stipulated prices, under a collateral, independent contract, can escape an obligation to pay for them upon the ground merely that the seller, which owned the goods was an illegal combination or trust." Continental Wall Paper Co. v. Louis Voight \& Sons Co., 212 U.S. 227, 261 (1909).

${ }^{17}$ Justice Holmes in Continental disagreed strongly about this resolution of the conflicting interests. He indicated that, to him, the unjust enrichment argument was more important. It was, he said, the overriding consideration. See 212 U.S. at 271 . See also Kelly v. Kosuga, 358 U.S. 516, 520-21. This point is discussed at note 56 infra.

${ }^{18}$ See cases cited in note 4 supra. 
lower courts. ${ }^{19}$ After this long silence on the part of the Supreme Court, Bruce's Juices ข. American Can $\mathrm{Co}^{20}$ was greeted by some commentators as the beginning of a new era. ${ }^{2 t}$ That case involved an alleged violation of the RobinsonPatman Act. ${ }^{22}$ For the first time, the Court analyzed the purpose of the statute, the intent of its drafters and the function which might be served by recognition of the defense of antitrust illegality. The Court, however, held that the Robinson-Patman remedies were exclusive, and rejected the defense. ${ }^{23}$ Perhaps the most promising feature of Justice Jackson's opinion was his extensive analysis of the problem of unjust enrichment which is so significant in these cases. After the very thorough attention given to all of these problems, the Court's ultimate resort to the collateral-inherent formula is somewhat disappointing.

Beloit Culligan Soft Water Service, Inc. v. Culligan, Inc.. ${ }^{24}$ was a suit for a declaratory judgment. The buyers, Culligan dealers, were seeking to have determined the validity of dealership franchises entered into between the seller and themselves. The contracts granted the buyers exclusive territorial dealership

"See Lockhart, Violation of the Antitrust Laws as a Defense in Civil Actions, 31 MnN. L. REv. 507, $531 \mathrm{n} .130$ (1947). With the possible exception of the two most recent decisions cited in note 2 supra, the cases which have been decided in the lower courts since 1947 are no more helpful than those cases decided prior to that date. Among the more recent lower court decisions are Adams Dairy Co. v. St. Louis Dairy Co., 260 F.2d 46 (8th Cir. 1958); United Artists Corp. v. Strand Productions, 216 F.2d 305 (9th Cir. 1954); Blue Bell Co. v. Frontier Refining Co., 213 F.2d 354 (10th Cir. 1954); Consolidated Gas, Electric Light \& Power Co. v. Pennsylvania Water \& Power Co., 194 F.2d 89 (4th Cir. 1952), cert. denied, 343 U.S. 963 (1952); Kogod v. Stanley Co. of America, 186 F.2d 763 (D.C. Cir. 1950); Carter v. Twentieth Century-Fox Film Corp., 127 F. Supp. 675 (W. D. Mo. 1955); Jamaica Sash \& Door, Inc. v. Prudential Improvement Service, 137 N.Y.S. 2d 593 (1954). See also cases cited in note 3 supra.

20330 U.S. 743 (1947).

${ }^{21}$ See, e.g., Lockhart, supra note 19, at 548.

249 Stat. 1526 (1936), 15 U.S.C. $\$ \$ 13-13 a$ (1958). The buyer alleged that the seller had perpetrated an illegal price discrimination by virtue of a quantity discount arrangement which was not available to the buyer because his purchases were too small.

${ }^{23}$ The Court had relied previously on the notion of exclusiveness of the statutory remedies. The clearest invocation of this argument is to be found in Wilder Mfg. Co. v. Corn Prod. Ref. Co., 236 U.S. 165, 175 (1915), where Chief Justice White formulated a somewhat puzzling rationale. It is his major premise which is most onen to question: "Because of the destruction of the powers conferred by the statute and the frustration of the remedies which it creates which would obviously result from admitting the right of an individual as a means of defense to a suit brought against him on his individual and otherwise inherently legal contract to assert that the corporation or combination suing, had no legal existence in contemplation of the Anti-Trust Act." The thesis seems to be that because the declaration against antitrust violations is a public policy, only public officers, here the attorney general, should be able to invoke the provisions of the act. But query what becomes of this argument when Section 4 of the Clayton Act, authorizing private suits by persons aggrieved by conduct in violation of the antitrust statutes, is considered. This section was passed by Congress on October 15, 1914. Wilder was argued November 9, 1914, and decided February 23, 1915. The Chief Justice appears to have disregarded the impact of this statute in his opinion.

21274 F.2d 29 (7th Cir. 1959). 
privileges, the right to buy their requirements of the goods manufactured by Culligan, and the right to use the Culligan name. The benefit to the seller was that the buyers were forbidden to purchase supplies from anyone else, and were obligated to use their best efforts in promoting Culligan products. AIthough the provisions varied, each contract also obligated the buyer to purchase a minimum number of soft water units for a specified period, ranging from five to ten years. Each contract contained a typical severability clause.

The seller set up the affirmative defense that the requirement that the buyer deal exclusively with the seller was in violation of Section 3 of the Clayton Act. ${ }^{25}$ This, it was alleged, rendered the entire agreement unenforceable under the doctrine of Kelly v. Kosuga and the prior cases. The Court of Appeals for the Seventh Circuit accepted the claim of illegality. ${ }^{26}$ Like the Supreme Court in Kelly, however, it declared the illegal portion of the agreement to be severable from the remainder of the contract, which was held to be valid and enforceable. The court was able to come to this result only by relying on the fully performed promise of the buyers to take a minimum number of the seller's manufactured units for a specified term. This, the court concluded, constituted sufficient consideration for the seller's obligation to furnish the buyers' requirements for the remainder of the contract term. The court also commented on the language of section 3 , indicating that since that section appeared to be directed only against sellers, ${ }^{27}$ the buyers, not being chargeable with a violation of the act by virtue of the illegal provisions of the contract, should not be denied enforcement because of the seller's illegal acts. The buyer, the court concluded, was not in pari delicto with the guilty seller. ${ }^{28}$

Tampa Elec. Co. v. Nashville Coal Co. ${ }^{29}$ raised similar problems. That was a

2538 Stat. 731 (1914), 15 U.S.C. § 14. (1958).

${ }^{26}$ On October 31, 1956, the Federal Trade Commission filed a complaint against Culligan charging a violation of Section 3 of the Clayton Act by requiring its dealers to purchase and deal in Culligan's soft water products only. Culligan agreed to a consent decree effective May 23,1957 . The court did not rely exclusively upon the consent decree in reaching its conclusion on the issue of illegality; it appears to have had little trouble, apart from the decree, in finding the violation.

${ }^{27}$ This aspect of the court's opinion is discussed at pp. 773-76 infra.

${ }^{28}$ The quotation from Corbin on Gontracts relied upon by the court (274 F.2d 29 at 35) deserves close attention: "If a bargain is illegal, not because a performance promised under it is an illegal performance, but only because the party promising it is forbidden by statute or ordinance to do so, the prohibition is aimed at that party only and he is the only wrong doer. ... The other party, being himself subject to no prohibition or penalty, may even be one of the class of persons for whose protection the prohibitory statute was enacted.

"In these cases the refusal of all remedy against a party to the illegal bargain would penalize" the very persons for whose benefit the making of such a bargain is prohibited or declared il-. legal. In such cases, in order to attain the purposes of the law, the courts have frequently enforced the bargain by one or more of the usual remedies, in favor of a party for whose beneit the law was intended and against a party toward whom the prohibition or penalty was directed. ... There is no reason why, in a case otherwise proper, a decree for specific performance should not be granted." 6 CORBIN, CoNTRACTs $\$ 1540$ (1951).

${ }^{29} 276$ F.2d 766 (6th Cir. 1960). 
declaratory judgment action by buyer against seller to determine the validity of a requirements contract for the purchase and sale of coal as fuel for an electric generating station for a term of twenty years. The defendant coal company contended that the requirements provision violated Section 3 of the Clayton Act. In the district court the defense was sustained without reference to the line of antitrust illegality cases here discussed. ${ }^{30}$ That court relied wholly upon National Transformer Corp. v. France Mfg. Co. ${ }^{31}$ In the court of appeals many of the same arguments were raised as were considered in the Beloit case. The Tampa contract, however, did not have so many different terms as the Beloit contracts. The Tampa court was unable to find grounds satisfactory to it for severance of the illegal exclusive dealing provisions from the remainder of the contract. The court admitted, inferentially, the plaintiff-buyer's contention that Section 3 of the Clayton Act was directed only against the seller, but said nevertheless, that "the result of the contract had the proscribed effect," 32 and therefore, the contract was illegal and unenforceable.

\section{Divisibuity of "Partially Illegal" Contracts}

Kelly ข. Kosuga appears to be the first case in which the Court has faced squarely the problem of what to do when an important term of the contract itself admittedly constitutes an antitrust violation. ${ }^{33}$ In order to justify its refusal to apply the defense, the Court chose to declare the non-delivery agreement severable from the agreement of purchase and sale. The purchase and sale constituted, it was said, "an intelligible economic transaction in itself." come to this conclusion the Court had to ignore the fact that the defendant had purchased primarily to secure the plaintiff's promise of non-delivery on the futures market. The plaintiff, in turn, had promised to withhold his onions from

${ }^{30} 168$ F. Supp. 456 (M.D. Tenn. 1958).

$31215 \mathrm{~F} .2 \mathrm{~d} 343$ (6th Cir. 1954). Even the portion of the opinion quoted in reliance by the district court in Tampa belies the applicability of National Transformer as a precedent: "It may be here emphasized that a contract which cannot be performed without violation of a statute is illegal and void. Where parties are in pari delicto, the law will leave them where it finds them, and all relief is refused because of the public interest.... The defendant may assert the invalidity of an agreement, even though he is a participator in the wrong. ... The defense of illegality is allowed, not as a protection to the defendant, but as a disability to the plaintiff." Id. at 361. Query whether the parties in Tampa were in pari delicto, whether the public interest required recognition of the defense, whether the plaintiff in Tampa was really a participator at all in the wrong, or whether it was fair to thus disable the plaintiff.

${ }_{22}$ Tampa Elec. Co. v. Nashville Coal Co., 276 F.2d 766, 773 (6th Cir. 1954).

${ }^{33}$ The older cases-e.g. Connolly and Continental-presented the problem of contracts which were legal in themselves and which were alleged to be unlawful only because of connection with some illegal activity outside the terms of the contract itself. The argument there was that this "external" illegality was imported into the contract. Thus the Supreme Court measured the proximity of the illegal activity to the contract and decided whether the contract was inherently or merely collaterally unlawful. In Kelly, however, it was a term of the contract itself which was alleged, and admitted procedurally, to constitute the violation of law. The question could not logically be one of proximity, but had rather to be one of severability, if the case were to be decided in the language of the traditional maxims.

${ }^{34}$ Kelly v. Kosuga, 358 U.S. 516, 521 (1959). 
the futures market principally in order to induce the defendant to buy them. The Court seemed by its application of the doctrine of divisibility to mean that because people generally buy and sell onions without this sort of illegal agreement as a "rider," they would have done so in this case. It is questionable whether the Court really needed to rely on so unrealistic a rationale to justify a sound result.

Nevertheless, it is understandable that the Court felt obliged to articulate its opinion in traditional language, even though its reasoning might, as the opinion admitted, be "circular." 35 The plaintiff's motion to strike forced the Court to recognize the illegality of the non-delivery agreement in the contract. This made it difficult, if not impossible, for the Court to rely solely upon the traditional collateral-inherent distinction. ${ }^{36}$ The Court therefore seized upon the doctrine of divisibility.

In Beloit the court was forced by the pleadings to adopt the difficult reasoning of divisibility utilized in Kelly. The defendant-seller contended that if the allegedly illegal term were stricken, the contract would be devoid of consideration to support his obligation to honor the exclusive territories of the dealers and to sell to them their requirements. The answer of the court to this argument was that there was indeed such other consideration. The buyers had promised to take a minimum number of units per year for a fraction of the contràct term, and had performed this obligation. The court relied upon this fulfilled term of the contract to support the remaining obligations of the seller.

The Beloit court was not so unrealistic as to urge, as did the Supreme Court in Kelly, that absent the illegal term, the contract constituted "an intelligible economic transaction in itself." In Beloit, as in Kelly, the reformed contract imposed upon the parties was so one-sided that it is difficult to understand how the court could have found adequate remaining consideration. The most likely explantion is that both courts were led to this result by considerations quite apart from the technical legal issue of divisibility. ${ }^{37}$ The equities of the parties

35 'And while analysis in terms of 'divisibility' or some other verbal formula may well be circular;..." 358 U.S. at 521.

${ }^{36}$ See note 33 supra.

${ }^{37}$ Counsel for Beloit Culligan strongly emphasized the good faith of their clients in the brief:

"The plaintiffs, pursuant to their individual franchise agreements with Culligan and in reliance thereon, have invested substantial sums of money to develop the territories which were granted to them by Culligan, and have at the present time a substantial capital investment in their respective business operations....

"The plaintiffs have also expended large sums to develop an intangible asset of substantial value in the name 'Culligan' in their respective areas, having done this in reliance upon the duration of their franchises and the exclusivity of their territories. . . .

"Included in such expenditures by plaintiffs has been extensive advertising through such media as newspapers, billboards, radio, television, and direct mailing. Advertising conducted by plaintiffs is done under the name 'Culligan Soft Water Service' and plaintiffs do not advertise the name or names of their respective proprietors. ..."

Brief for Plaintiffs-Appellees; p. 7, Beloit Culligan Soft Water Service, Inc. v. Culligan, Inc., 274 F.2d 29 (7th Cir. 1959). 
appear to have played a major role in both cases in influencing the courts to reach a result which seems satisfactory, even though in both cases it was artificially rationalized.

The approach of the Tampa court to the problem of divisibility is similarly ambiguous. The contention of severability was given short shrift by the court's conclusion that "the appellant [buyer] is attempting to have declared valid the very provisions which made the agreement invalid." 38 It is not at all clear that this was true. The buyer in Tampa was seeking to have declared valid and binding the obligation of the seller to furnish the buyer's requirements of coal for the term of the contract. The provisions of the contract which made it illegal were not those relating to the obligation of the seller, but rather those which tied the buyer to the seller and prevented him from dealing in coal for the particular generating station with anyone else. There is little doubt that the buyer did not entertain much solicitude for the welfare of the seller. As a matter of fact, he would no doubt have been happy to have been excused from the potentially onerous limitation which required him to deal solely with the defendant. He was seeking only to hold the seller to his agreement, which was itself not illegal.

The suggested impact of the courts' weighing of the equities of the parties is demonstrated emphatically by Tampa. In that case the court could have found divisibility by relying on a term of the contract precisely parallel to that relied on in Beloit. As a matter of fact, under the Beloit rationale, the contract in Tampa undoubtedly presented a stronger case for divisibility that did the Beloit contract. The buyer in Tampa, like the buyer in Beloit, was obligated to take a stated minimum of the product. Unlike the Culligan dealers, however, Tampa was obligated to such a minimum purchase for the whole of the contract term. Surely this obligation was more of a quid pro quo for the seller's obligation than was the short-term, already fulfilled obligation seized upon by the Beloit court to justify severance. How, then, is Tampa to be distinguished from Beloit?

The Tampa court did not help when it said only that the Beloit case was distinguishable "for the same reasons" 39 that made Kelly inapplicable. The only reason given in the opinion to which this conclusion could possibly refer was that the contract in Tampa, unlike those in Kelly and Beloit, was not severable. This merely argues the conclusion.

The factors which moved the Tampa court to recognize the defense are not explicit in the opinion. It is apparently true, however, that there were no facts in Tampa similar to those in Beloit which motivated a "pro-plaintiff" attitude. ${ }^{40}$ It is likely that this is the only realistic ground for distinguishing the cases. No manipulation of the doctrine of divisibility seems adequate to justify opposite

${ }^{38}$ Tampa Elec. Co. v. Nashville Coal Co., 276 F.2d 766, 774 (6th Cir. 1960).

"Ibid.

${ }^{10}$ See note 37 supro. 
results on facts which were so similar. The conclusion reached by Professor Corbin is in accord with this analysis:

It is generally assumed that enforceability depends on "divisibility," and that "divisibility" depends on the terms of the bargain and the expressed intention of the parties. It is believed, however, that such an assumption makes the cart pull the horse in most cases, and that a bargain is described as "divisible" only after the court has determined on grounds of policy that a part of it should be enforced.... [T]he court is in fact rendering its decision on the basis of its judicial instinct for "justice" or of some inarticulate major premise as to the requirements of "public policy." $4 \mathrm{I}$

\section{The Policy Conflicts}

It has been suggested in the foregoing discussion that the Court has struggled within the framework of the traditional maxims to achieve justice between the parties to a contract tainted with illegality. The policies which appear to have motivated the Court in its application of the defense of illegality seem clear. On the one hand the Court is understandably unwilling to enforce a contract where the judgment of the Court would compel the performance of an unlawful act. ${ }^{42}$ On the other hand, the Court has been impressed by the argument that the defense should not be allowed, and defendants thereby unjustly enriched, where it is possible to enforce the contract without the compulsion of an illegal act. ${ }^{43}$ The Court has also indicated its concern with the disproportionately heavy penalties which might be assessed against a plaintiff if the defense were to be sustained and the contract voided in its entirety..$^{44}$

It is infrequent that these conflicting policies are capable of clear application. Rarely does a plaintiff request a judgment which would compel the performance of an illegal act by either party. It is also infrequent in these cases that the value already received by the defendant is as great as the value which the plaintiff requests of him through compulsory performance of his contractual obligations. ${ }^{45}$ In the marginal cases the Supreme Court has struggled with the traditional maxims in an effort to make them express the complex value judgments which the Court is making.

11 Corbin, Contracts $\$ 1520$ (1951).

${ }^{2}$ Speaking of the opinion in Continental, for example, Justice Brennan stated in Kelly: "The Court was of the opinion that to give judgment for the excessive purchase price so fixed in favor of such a vendor would be to make the courts a party to the carrying out of one of the very restraints forbidden by the Sherman Act. 212 U.S., at 261." Kelly v. Kosuga, 358 U.S. 516,520 (1959).

13 "Past the point where the judgment of the Court would itself be enforcing the precise conduct made unlawful by the Act, the courts are to be guided by the overriding general policy, as Mr. Justice Holmes put it, 'of preventing people from getting other people's property for nothing when they purport to be buying it." "Kelly v. Kosuga, 358 U.S. 516, 520-21 (1959).

${ }^{44}$ See Kelly v. Kosuga, supra note 43 , at 521.

${ }^{45}$ The exceptional case is Kelly v. Kosuga, where the contract price sued for actually appears to have been the fair market price at the date of the contract. More often an excessive price is involved. See, e.g., Bruce's Juices v. American Can Co., 330 U.S. 743 (1947). 
The treatment of the defense of antitrust illegality by the Supreme Court may indicate that the Court has gone further than is necessary in enforcing contracts in order to avoid injustice. As has already been noted, in a line of cases, all of which show some illegality either connected with or as a part of the contract in suit, only once has the Supreme Court, in Continental W all Paper, sustained the defense. The extreme restrictiveness of the Kelly result makes it plain that the defense will be successful, if at all, only in the clearest cases of contracts which are illegal in the very provisions sought to be enforced, or in some provision which the Court will be unable to sever from the portion of the contract directly in suit. Justice Brennan, in Kelly, confined the scope of the defense to that "point where the judgment of the Court would itself be enforcing the precise conduct made unlawful." "46 The failure of the Court to extend the analysis begun in Bruce's Juices is puzzling, and disappointing. ${ }^{47}$

The strongest fear held by the courts appears to be that the defendant will profit unjustly if the defense is sustained and the contract vitiated. The Kelly opinion urged, for example, that "the courts are to be guided by the overriding general policy ... 'of preventing people from getting other people's property for nothing when they purport to be buying it." ",48

Persuasive as this argument is, it does not necessarily dictate the rejection of the defense. In the first place, the argument cuts both ways. If the plaintiff, for example, is allowed to enforce a discriminatory price against the defendant, his gain, made by virtue of the defendant's ignorance, inexperience or bargaining impotence, may not improperly be described as a windfall. In answer to this, it must of course be admitted that the plaintiff ordinarily will stand to lose much more by non-enforcement of the whole contract than the defendant will lose as a result of being compelled to pay a discriminatory price.

Nor does the argument apply in all situations. The argument is irrelevant, for example, when contracts executory on both sides are in question. There was no reason for the Court, in Small Co. v. Lamborn \& Co., ${ }^{49}$ to reject the defense that the plaintiff had entered into a combination with others to create a false picture of a sugar shortage and to sell at an exorbitantly high, fixed price. The defendant paid the excessive contract price for all the sugar that it accepted, but refused the balance of the sugar after the true market conditions became obvious. The undelivered part of the contract was executory; recognition of the defense would not have been inconsistent with the standard laid down by Justice Holmes ${ }^{50}$ because the defendant was asking for no windfall.

In non-executory situations, the argument against unjust enrichment could be dealt with most equitably by application of principles of restitution. The de-

${ }^{16}$ Kelly v. Kosuga, 358 U.S. 516, 520 (1959).

${ }^{47}$ See p. 763 supra.

18358 U.S. at 520-21, quoting from Justice Holmes' dissent in Continental Wall Paper Co. v. Louis Voight \& Sons Co., 212 U.S. 227, 271 (1909).

19267 U.S. 248 (1926).

${ }^{50}$ See text at note 48 supra. 
fendant in Bruce's Juices developed in his brief the theory that "discriminatory prices over and above the fair value of the goods cannot be collected by the seller." 51 The majority unjustifiably proceeded as if the buyer were seeking to avoid all liability for the cans sold to it by the plaintiff. Justice Murphy, dissenting; made it clear that the buyer was not trying to get something for nothing, but the majority chose "to sit idly by and allow sellers to collect illegal price differentials." ${ }^{25}$ The plaintiff in Kelly asserted the right to a quasi-contractual recovery, even if the defense of illegality were sustained, for it made no difference to him. ${ }^{53}$ The contract price of $\$ 960$ per car was apparently the market price for onions at the date of the contract; the Court agreed that there had been "a lawful sale for a fair consideration." 54

It is true that allowance of quasi-contractual relief in cases of this sort would be inconsistent with a long-standing tradition which has denied such relief if there can be no recovery on the contract..$^{55}$ Nevertheless, it seems preferable that the Court should fly in the face of tradition rather than put itself in a position where it is able only to give an unfair recovery, or no recovery at all. ${ }^{56}$ The Court has often acted as if only these two courses were open to it. The Court has tried to select the least unjust alternative in each case; if it would determine upon a middle-ground-that of allowing quasi-contractual recovery-it would be in a position to achieve the most just result.

Tampa and Beloit demonstrate the impact of the unjust enrichment argument. It was quite clear in Beloit that the court was influenced in its decision by the fact that the buyers apparently had in good faith performed all of their obligations under the contracts to the date of the suit. The court seemed impressed with the overwhelming unfairness of allowing the seller either to force the buyer to accept another less desirable contract or to escape altogether from his obligations. The buyer's completed performance of some of the material terms of the contract was benefit which the seller had received for which he could not compensate the buyers without performing his obligations under the contract..$^{57}$ In Tampa, on the other hand, there is no indication that the court

51 Statement of petitioner's case by Justice Murphy, dissenting, Bruce's Juices v. American Can Co., 330 U.S. 743, 758 (1947). See the Petition for Writ of Certiorari in the same case.

52330 U.S. at 765.

${ }^{53}$ See Brief for Respondent, pp. 26-28, Kelly v. Kosuga, 358 U.S. 516 (1959).

64358 U.S. at 521 (Emphasis suppled.)

${ }^{55}$ See note 3 supra.

${ }^{56}$ Compare, e.g., Connolly, where the plaintiff obtained full recovery, apparently of an excessive price, and Continental, where the plaintiff was denied recovery in toto, despite the fact that the defendant had received a large amount of goods for which he had not paid.

57 'Relying upon their franchises, the plaintiffs invested large sums of money in their businesses which were conducted under the Culligan name. In the early years of operation they uniformly operated at a loss. Several of the plaintiffs have committments to advertise Culligan products for considerable periods in the future. The years of effort and expenditure 
grappled with the problem of unjust enrichment: the contract was wholly executory on both sides.

The Court has given great weight to the argument that a refusal to enforce contracts because of antitrust illegality might impose unduly burdensome or capricious penalties on the plaintiff. ${ }^{58}$ But again, this is more an argument for application of principles of restitution than it is for non-application of the defense. Recognition of the defense in executory contract cases would not require the imposition of any damages. With these modifications, the only penalty that broader recognition of the defense would impose would be the disallowance of illegal profits sought to be realized on a tainted transaction.

The third argument which has been given much weight in the cases is that the defense of antitrust illegality should be restricted severely because of the exclusiveness of the statutory antitrust sanctions. ${ }^{59} \mathrm{It}$ is true, as the Supreme Court has noted on several occasions, ${ }^{60}$ that Congress did not explicitly authorize application of this doctrine as a remedy in addition to those provided by the statutes. ${ }^{61}$ The inclusion of an affirmative provision authorizing this defense as a sanction was discussed during committee preparation of the Sherman Act. ${ }^{62}$ Such a provision was not included. It is to be noted, however, that the remedy, not having been considered separately, nor even debated on the floor of Congress, was not explicitly rejected. To argue then that Congress intended the statutory remedies to be exclusive is to contend what it is impossible to prove. The intent might as well have been to allow the courts latitude to develop the general doctrine of illegality in this area as they found necessary.

It has also been suggested that the Court has refused to apply the defense of antitrust illegality more broadly because of a reluctance to complicate the

of funds by plaintiffs have borne fruit, and in recent years, the plaintiffs usually have been operating at a profit. Their businesses under the Culligan name have become well established. Such good faith conduct by plaintiffs might, in itself, be grounds for holding there was no lack of mutuality in the contracts we are considering." Beloit Culligan Soft Water Service, Inc. v. Culligan, Inc., 274 F.2d 29, 34 (7th Cir. 1959).

${ }^{88} \mathrm{It}$ is easily seen that to deny a plaintiff all relief because of a violation might involve the loss of huge sums of money, or of goods of a similar value. Such "penalties" for a violation could conceivably be wholly out of proportion to the violation involved.

${ }^{59}$ The legislative history on this point is examined exhaustively by Lockhart, supra note 19, at 508-12. His conclusion is that "it cannot be said that Congress has ever affirmatively" indicated either its disapproval of the defense, or its dissatisfaction with the manner in which the defense has been handled in the courts." Id. at 512. It is going a considerable distance to contend in the face of such a legislative history that the very absence of congressional authorization for the broader application of the defense indicates a congressional intent that contracts contrary to the legislative policy expressed in the antitrust laws ought to be enforceable in the courts.

${ }^{\text {Co }}$ See particularly Wilder Mfg. Co. v. Corn Prod. Ref. Co. 236 U.S. 165 (1915); Bruce's Juices v. American Can Co., 330 U.S. 743 (1947); Kelly v. Kosuga, 358 U.S. 516 (1959).

61 See Lockhart, supra note 19, at 508-12.

62 See note 59 supra. 
relatively simple contract litigation with lengthy, involved and expensive antitrust issues. If the Court is afraid that this would result in the question of the violation being tried as a "side issue," be accorded sufficient protection, the argument would appear to have little merit. The Court itself may regulate the standards of proof and the extent of the investigation so as to assure fair consideration of the issues. If the fear is that these privately initiated antitrust suits will interfere with the activities of the Justice Department in this area, ${ }^{64}$ there is again little objection. Section 4 of the Clayton Act ${ }^{65}$ indicates congressional approval of broad private enforcement of the antitrust statutes. If the Court's objection is simply that there will be too many cases which will be too long and complex if the defense is applied more broadly, it seems reasonable to ask whether the courts are not evading their duty. Fear of diverse state court interpretation of the antitrust acts may be justified; ${ }^{66}$ but again, the Court may control this problem by review. ${ }^{67}$

While there may be reason to believe that defendants will utilize the defense as a dilatory tactic, there is no cause to believe that it would prove any more successful (or troublesome, depending upon the point of view) than it is today. Indeed, the only way that it would be possible to make the defense unavailable for delaying purposes would be either to refuse to recognize it at all, or to sustain it in all cases. So long as there is any question whether there is a violation, or, assuming that there is one, whether the defense will be sustained, it is likely to be used by the defendant who wants to buy time and forestall-decision.

Finally, it has been argued that the defense of antitrust illegality ought to be given restricted application because it could not be a sufficiently effective sanc-

${ }^{63}$ See Note, The Sherman Act as a Clean Bands Deferse, 50 YaLE L.J. 1114 (1941).

64 Ibid. See also Kelly v. Kosuga, 358 U.S. 516, 520 (1959): "If the defense of illegality is to be allowed as a collateral method of enforcement of the antitrust laws, as the breadth of petitioner's argument suggests, it must be said that his theory creates a very strange class of private attorneys general." But query whether this "very strange class of attorneys general" is significantly different from that created by Section 4 of the Clayton Act?

${ }^{65} 38$ Stat. 731 (1914), 15 U.S.C. $\$ 15$ (1958), authorizing private suit by persons aggrieved by acts in violation of the antitrust statutes.

${ }^{66}$ See Note, The Sherman Act as a Clean Bands Defense, supra note 63. See also the implicit statement of the argument in Kelly v. Kosuga, 358 U.S. 516, 519 (1959).

${ }^{67}$ Why the Court should have more trouble in imposing uniform statutory interpretation on state supreme courts than it has had in imposing it upon federal courts is a part of this argument which is not articulated. In either case, a federal statute is involved and the Court clearly has the power of review. At any rate, even in that small number of cases where the Court now agrees to the application of the defense, the same problem, if any, exists. It is probably reasonable to suggest that the Court ought not to have as much trouble in controlling possbile diverse interpretations of the antitrust statutes as it has in controlling diverse application of the ambiguous maxims which have resulted in such restrictive recognition of the defense itself. 
tion to merit broader recognition. ${ }^{68}$ Even if this is true, it does not really meet the opposing contention that contracts inimical to the antitrust policy should not be enforced because of their inconsistency with a legislatively articulated standard of conduct. Furthermore, it seems reasonable to speculate that the defense, if applied more broadly, would have some deterrent effect on businessmen who, in the exercise of business judgment, would be likely go to some lengths to reconcile their practices with the statutory standards in order to avoid being caught up in complicated, lengthy and expensive, as well as potentially disreputable, antitrust litigation whenever they might seek judicial aid to enforce their contracts. At any rate, it seems unrealistic to argue that the defense would have no effect whatsoever. Furthermore, this argument is obviously not apposite when the goal sought is not necessarily broader enforcement of the statutes, but greater justice between the parties.

This discussion of the arguments which have been pressed against recognition of the defense of antitrust illegality indicates two significant conclusions. First, that the most persuasive arguments which have been presented to restrain application of the defense are really more arguments for application of principles of restitution in this area than they are arguments against application of the defense. Secondly, that if the Court were to adopt principles of restitution, there are no persuasive arguments to prevent the Court from applying the defense more broadly to achieve greater justice and to frustrate illegality in a greater number of cases.

\section{The Defense of Iltegality Based on Sectron 3} of THE Clayton Act

The foregoing discussion has dealt with the defense of antitrust illegality in general. The decisions in Beloit and Tampa, in addition to considering the general problems already discussed, raised for the first time the question of who may assert the defense when it is grounded in a claim of illegality under Sec-

${ }^{68}$ Lockhart posits two arguments against the effectiveness of the defense as an antitrust sanction: "Proof of the anti-trust violation against a strongly entrenched, well financed defendant often entails financial and legal burdens beyond the capacity of any litigant except the government itself. ... In many cases the private party will refrain from challenging an antitrust violation because he fears the loss of business advantage or possible trade reprisals if he breaks with the violator." Lockhart, supra note 19, at 571. Both of these objections are carryovers from the problems encountered by the private treble damage action. But, in the first place, there will already have been a break between the plaintiff and the defendant or there would be no suit. The first-mentioned problem is nothing more than the common objection to the adversary process. The rich and powerful party, who is able to "buy" the best lawyers, the best investigators and the most information, always has an advantage over the smaller and weaker litigant. This argument may, in fact, apply less in the antitrust cases than in other areas; for here the government is likely to skim off the most strongly entrenched and most financially able monopolists, leaving those who remain relatively less powerful when compared with the disadvantaged defendant who asserts the antitrust violation as a defense. 
tion 3 of the Clayton Act. ${ }^{69}$ In light of the divergent views expressed in these two opinions, and because of the probability that the Court will be squarely confronted with this question early in the 1960 term, ${ }^{70}$ a brief analysis of the problem seems desirable.

The unanimous opinion in Beloit and the dissent in Tampa both argued that - Section 3 of the Clayton Act applies only against sellers. Under this interpretation, a contract containing terms violative of this section should be enforceable at the instance of buyers in all cases where the seller's only defense is Section 3 Clayton Act illegality, since it cannot be said that the buyer should be denied relief because his own acts were illegal and he was in pari delicto with the guilty seller.

The majority in Tampa challenged this view on the ground, apparently, that section 3 is not directed against sellers only, but also against certain restraints of competition which result from abusive contractual terms, such as exclusive dealing agreements. It is also possible to argue that this section is directed against buyers as well as sellers, if the former are responsible for the contract provisions which result in restraints of the type described in the section.

Both of these latter viewpoints must, however, cope with the language of section 3, which, read literally and in a straightforward manner, appears to be directed only against activities of the seller which result in a contract whose terms impose the restraints described. It is extremely difficult to extract from this section a prohibition of the contract itself. It is even more tenuous to argue that a buyer, even one who obviously controlled the bargain and is responsible or the agreement, may be charged under section 3. Either of these arguments must be made in the face of the statutory language. In addition, it should be noted that, with Section 1 of the Sherman Act (which in terms makes contracts in restraint of trade unlawful) as an example, Congress could surely have formulated more appropriate language to express a prohibition of contracts and buyers' acts, as well as sellers' acts. The legislative history is convincing that Congress intended to prohibit a specific abuse which was committed by sellers. ${ }^{71}$

${ }^{69}$ Section 3 of the Clayton Act, 38 Stat. 731 (1914), 15 U.S.C. $\$ 14$ (1958), reads as follows, in its pertinent parts: 'It shall be unlawful for any person engaged in commerce, in the course of such commerce, to lease or make a sale or contract for sale of goods, wares, merchandise, machinery, supplies, or other commodities, whether patented or unpatented, ... on the condition ... that the lessee or purchaser thereof shall not use or deal in the goods, ... of a competitor or competitors of the ... seller, where the effect of such a lease, sale, or contract for sale or such condition, agreement, or understanding may be to substantially lessen competition or tend to create a monopoly in any line of commerce." (Emphasis supplied.)

${ }^{70}$ The time for filing for certiorari in the Beloit case has passed. Tampa Electric Co.'s petition for certiorari has been granted. 363 U.S. 836 (1960). It is to be hoped that the Supreme Court will take this opportunity to clarify this traditionally difficult area of the law.

${ }^{71}$ See, e.g., the argument taken from the legislative history in the Brief for PlaintiffsAppellees, p. 27, Beloit Culligan Soft Water Service, Inc. v. Culligan, Inc., 274 F.2d 29 (7th Cir. 1959): " "[Section 3] is designed merely to prevent this unfair trade practice now so common throughout the country, and which is generally regarded by everyone who has given the subject any serious consideration as unfair to the local dealer and to the community and as monopolistic in its effects.' (Emphasis added.)" See H.R. REP. No. 627, 63d Cong. 2d Sess. 11 
It does not appear that this section was intended to prohibit anything other than acts of sellers. ${ }^{72}$

Judicial comment prior to Tampa and Beloit on this phase of the operation of section 3 is of little direct value, since the particular point was never decided. Indirect language in the Standard Stations case, ${ }^{73}$ for example, would appear to indicate that the Supreme Court feels that section 3 is a prohibition of abusive contracts. An equally strong case may be made from the language of United $S h o e^{74}$ for the position that the section applies only against sellers. On the basis of the legislative history and the apparently clear statutory language, the better

(1914). The reply brief of the defendant did not touch upon the legislative history. The principal brief for the defendant, while purporting to rely on the legislative intent, did not refer to the legislative history.

72 No cases have been found in which a buyer or lessee has been charged with a violation of Section 3 of the Clayton Act.

${ }^{73}$ In Standard Oil of California and Standard Stations, Inc. v. United States, 337 U.S. 293, 306-07 (1949), the Supreme Court said:

"Requirements contracts, on the other hand, may well be of economic advantage to buyers as well as to sellers, and thus indirectly of advantage to the consuming public. In the case of the buyer, they may assure supply, afford protection against rises in price, enable long-term planning on the basis of known costs, and obviate the expense and risk of storage in the quantity necessary for a commodity having a fluctuating demand. From the seller's point of view, requirements contracts may make possible the substantial reduction of selling expenses, give protection against price fluctuations, and -of particular advantage to a newcomer to the field to whom it is important to know what capital expenditures are justified-offer the possibility of a predictable market."

The opinion in Standard Stations went on to indicate, in a very loose and indirect way, that this possible benefit of requirements contracts to buyers indicates that contracts resulting in the restraints described in section 3 are unlawful under that section.

${ }^{74}$ See Brief of Plaintiffs-Appellees, pp. 27-28, Beloit Culligan Soft Water Service, Inc. v. Culligan, Inc., 274 F.2d 29 (7th Cir. 1959): "[I]n United States v. United Shoe Machinery Corp., 234 F. 127 (E.D. Mo. 1916), aff'd., 258 U.S. 451 (1922), the Federal Courts reinforced the legislative intent expressed in the House Report (p. 139): 'It is hardly necessary to say, as it clearly appears from the language of the act, that the object of the statute invoked by the plaintiff was for the protection of the lessees and indirectly the public; Congress evidently presuming that the lessees accepted these leases under duress, and it is so charged in the complaint.'

"The dealers, therefore, are the very parties whom the statute is designed to protect. Culligan has cited no case, and we know of none, in which a purchaser was prosecuted for a section 3 violation.

"Clearly, the doctrine of in pari delicto should have no application to a purchaser where the seller may have transgressed section 3 of the Clayton Act. Any other holding would result, as here, in penalizing the plaintiffs for a wrong which only Culligan committed. This point is explicitly made in United States v. Unifed Stoe Machinery Corp., 234 F. 127 (E.D. Mo. 1916), $a f f^{\prime} d ., 258$ U.S. 451 (1922). The government there prosecuted the defendant for leasing machinery on the promise of the lessee not to purchase machinery from others, and for tying the lease of some machines to that of others. The defendant, United Shoe Machinery Corporation, contended that the lessees were necessary parties of the suit, arguing that the lessees' rights under the leases would be affected by the decree. To this contention the Court unequivocally stated (234 F. at p. 140): 'In the Court's opinion the lessees are not indispensable nor necessary parties to this action, as the relief prayed in the bill, if granted, can in nowise affect them or their rights, except that it may relieve them of an onerous, and, as the complaint alleges, illegal, burden.' (Emphasis added.)" 
view seems to be that taken by the Beloit court and the dissenting judge in Tampa.

It may, of course, be urged that this argument based on the statutory language has no significance because buyers will be held, in most cases, under Section 1 of the Sherman Act for the same transactions prohibited to sellers by Section 3 of the Clayton Act. ${ }^{75}$ Even if this is true in a large number of cases, it is surely not true in all cases. ${ }^{76}$ Furthermore, this point is no answer to the statutory argument; it merely gives good advice to defendants as to how to plead illegality.

For the reasons indicated, Beloit and Tampa seem irreconcilable. Beloit is probably more in harmony with the line of cases culminating in Kelly v. Kosuga. It is quite possible that the judgment of the Tampa court, sustaining the defense, will be reversed.77

\section{CONCLUSION}

The Supreme Court has made it clear that it is aware of the complex policy conflicts which arise when the defense of antitrust illegality is asserted. Recognition of the fact that the plaintiff would often be dealt with most unfairly by rigid application of the absolute rule against enforcement of illegal contracts, has led the Court to develop flexible exceptions to this rule. These exceptions have given the Court latitude to enforce contracts where it seems the fair thing to do, despite some taint of illegality. Yet it seems clear that the "all-ornothing" approach which necessarily follows from the traditional rule has not resolved the policy conflicts in the most satisfactory manner.

It is submitted that the inapplicability of the arguments of unjust enrichment and disproportionate penalties to executory contracts should be taken into consideration. Broader application of the defense in cases involving only executory contracts may be desirable in the interest of discouraging and frustrating unlawful schemes. In cases involving partially executed contracts, the adoption of principles of restitution would relieve the Court of the necessity of choosing between the two extremes-complete recovery or no recovery at all-both of which may be unjust, thereby making the defense more readily available in meritorious cases. Application of such principles would also do much to clarify this difficult area of the law, would add to predictability, and would make possible the achievement of greater justice between the parties to the contract.

\footnotetext{
${ }^{75}$ The suggestion that the great majority of the cases in which violations of Section 3 of the Clayton Act are found will also involve violations of Section 1 of the Sherman Act is made by Dean Edward H. Levi. For an indication of the justification for this position, see Director and Levi, Law and the Future: Trade Regulation, 51 Nw. U. L. Rev. 281, 289 (1956). See also Brief of Appellant, pp. 20-25, Beloit Culligan Soft Water Service, Inc. v. Culligan, Inc., 274 F.2d 29 (7th Cir. 1959).

${ }^{76}$ See the opinion of Justice Clark in Times-Picayune v. United States, 345 U.S. 594, 608-10 (1953).

${ }^{77}$ See note 70 supra.
} 